\title{
Necrotising Fasciitis: Clinical Evaluation and Treatment Results of 18 Patients
}

\author{
Nekrotizan Fasiit: 18 Hastanın Klinik Durumlarının ve Tedavi Sonuçlarının Değerlendirilmesi
}

\section{(1) Anıl Murat ÖZTÜRK', (1) Deniz AKYOL², (1) Onur SÜER', (1) Hüseyin Aytaç ERDEM², (1) Ilgın YILDIRIM ŞiMŞSiR², (1) Şebnem ŞENOL AKAR4, (1) Nadir ÖZKAYIN', (1) Meltem IŞIKGÖZ TAŞBAKAN²}

${ }^{1}$ Ege University Faculty of Medicine, Department of Orthopedics and Traumatology, Izmir, Turkey

${ }^{2}$ Ege University Faculty of Medicine, Department of Infectious Diseases and Clinical Microbiology, Izmir, Turkey

${ }^{3}$ Ege University Faculty of Medicine, Department of Internal Medicine, Division of Endocrinology, Izmir, Turkey

${ }^{4}$ Celal Bayar University Faculty of Medicine, Department of Infectious Diseases and Clinical Microbiology, Manisa, Turkey

\section{Abstract}

Introduction: Necrotizing fasciitis (NF) is a complicated and rapidly spreading soft tissue infection that affects the superficial fascia, skin, and subcutaneous tissue. In this study, we evaluated patients who were diagnosed with NF and treated in two tertiary-care educational university hospitals.

Materials and Methods: Patients diagnosed with NF in three centers (Ege University Department of Orthopedics and Traumatology and Department of Infectious Diseases and Clinical Microbiology and Celal Bayar University Department of Infectious Diseases and Clinical Microbiology) between November 2016 and December 2018 were retrospectively analyzed. The patients' demographic characteristics, significant risk factors for infection, sites of infection, models of surgical treatment, department(s) that performed the surgery, causative infectious agents, empirical and agent-specific treatment regimens and their duration, length of hospital stay, need for intensive care, and one month survival were evaluated.

Results: Eighteen patients (10 females, mean age 53.7 [19-86 years]) who were diagnosed with NF were included in the study. Diabetes mellitus, trauma/surgery history, and decubitus wound were the most common predisposing factors. The most common anatomic site was lower extremity $(\mathrm{n}=10,55.5 \%)$. All patients underwent surgical debridement. The most commonly isolated microorganisms were Escherichia coli $(\mathrm{n}=4), \mathrm{Klebsie} / \mathrm{a}$ pneumoniae, Proteus mirabilis, and Acinetobacter baumannii (each $\mathrm{n}=3$ ). Empirical treatment was initiated with meropenem in eight patients $(32 \%)$ and tigecycline in four patients (12.5\%), and the antibiotic was changed in five patients based on culture results. The mean duration of antibiotic therapy was 35.5 (9-68) days. The average hospital stay was 55 (11-186) days. Six patients (33.3\%) required intensive care during followup. The mortality rate was $16.6 \%$.

Conclusion: NF is a fulminant disease, and early diagnosis and effective multidisciplinary treatment are crucial for reducing mortality rates. When the diagnosis is suspected, early surgical debridement should be performed and empirical antibiotherapy should be started immediately.

Keywords: Multidisciplinary approach, complicated skin and soft tissue infection, linezolid, 'Laboratory Risk Indicator for Necrotizing Fasciitis' (LRINEC) score, ertapenem

\section{Öz}

Amaç: Nekrotizan fasiit (NF), yüzeyel fasyayı, deri ve deri altı dokuları tutan, çok hızlı seyir gösterebilen komplike yumuşak doku enfeksiyonudur. Bu çalışmada iki üçüncü basamak üniversite eğitim hastanesinde NF tanısı alıp tedavi edilen olguların değerlendirilmesi amaçlanmıştır.

Gereç ve Yöntem: Bu yazıda Kasım 2016 ile Aralık 2018 arasında üç merkezde izlenen (Ege Üniversitesi Ortopedi ve Travmatoloji ile Enfeksiyon Hastalıkları ve Klinik Mikrobiyoloji ve Celal Bayar Üniversitesi Enfeksiyon Hastalıkları ve Klinik Mikrobiyoloji) NF tanılı olgular retrospektif olarak incelenmiştir. Olguların demografik özellikleri, enfeksiyon gelişiminde rol oynayan risk faktörleri, enfeksiyonun yerleşim yerleri, uygulanan cerrahi tedavi modelleri, operasyona katılan branşlar, enfeksiyon etkeni olan mikroorganizmalar, uygulanan ampirik ve etkene yönelik tedavi rejimleri ve süreleri, hastanede yatış süreleri, yoğun bakım yatışlarının olup olmadığı ile bir aylık sağkalımları değerlendirilmiştir.

Cite this article as: Öztürk AM, Akyol D, Süer 0, Erdem HA, Yıldırım Şimşir I, Şenol Akar Ş, Özkayın N, Işıkgöz Taşbakan M. Necrotising Fasciitis: Clinical Evaluation and Treatment Results of 18 Patients. Mediterr J Infect Microb Antimicrob. 2019;8:9. 
Bulgular: Çalışmaya NF tanısı ile 18 olgu, [on kadın, ortalama yaş 53,7 (19-86) yıl] dahil edilmiştir. Diabetes mellitus, travma/operasyon öyküsü ve dekübit ülser en fazla saptanan predispozan faktörlerdi. En sık lokalizasyon alt ekstremitelerdi $(n=10, \% 55,5)$. En sık izole edilen mikroorganizmalar Escherichia coli $(n=4)$, Klebsiella pneumoniae, Proteus mirabilis ve Acinetobacter baumannii idi (her biri $n=3$ ). Ampirik olarak en sık meropenem $(\% 32)$ ve tigesiklin $(\% 12,5)$ tedavisi başlandı. Beş olguda kültürde üreme sonucuna göre antibiyotik tedavisi değiştirildi. Olgularda ortalama antibiyotik uygulanma süresi 35,5 gündü (9-68). Hastanede ortalama yatış süresi 55 gündü (11-186). Altı olgunun (\%33,3) izlemde yoğun bakım ihtiyacı oldu. Mortalite oranı \%16,6 idi.

Sonuç: NF fulminan seyirli ve yüksek mortalite oranlarına sahip bir hastalıktır. Erken tanı ve multidisipliner etkin tedavi mortalite oranlarını azaltmada çok önemlidir. Tanıdan şüphelenildiği anda erken cerrahi debritman yapılmalı ve hızlıca ampirik antibiyoterapi başlanmalıdır.

Anahtar Kelimeler: Multidisipliner yaklaşım, komplike deri yumuşak doku enfeksiyonu, linezolid, 'Laboratory Risk Indicator for Necrotizing Fasciitis' (LRINEC) skoru, ertapenem

\section{Introduction}

Necrotizing fasciitis (NF) is a complicated soft tissue infection that involves the superficial fascia, skin, and subcutaneous tissues and may follow a rapid course. If not treated properly, the resulting tissue necrosis spreads quickly and causes sepsis, leading to toxic shock syndrome and multiple organ failure, and ultimately ending in death ${ }^{[1-3]}$. Its incidence is approximately $0.4 / 100,000^{[4]}$. The reported rate of mortality associated with NF in the literature is $11-36 \%\left[{ }^{[5]}\right.$.

Necrotizing soft tissue infections were first described by Jones in 1871 , and were referred to as "hospital gangrene" at that time ${ }^{[6]}$. Despite the use of various terms such as necrotizing erysipelas, hemolytic streptococcal gangrene, non-clostridial gas gangrene, bacterial synergistic gangrene, and acute dermal gangrene. The name "necrotizing fasciitis" was first coined by Wilson ${ }^{[7]}$ in 1952. Inflammation and necrosis of the subcutaneous adipose tissue and deep fascia with muscle sparing are characteristic features of the disease $\mathrm{e}^{[7]}$.

Patient history may include insect bite, cut, abrasion, contusion, previous surgery, skin ulcer, burn, foreign substance, perirectal abscess, incarcerated hernia, or penetrating trauma ${ }^{[8,9]}$. It is often seen in the extremities and perineum, although it can develop anywhere in the body ${ }^{[10]}$. The most common comorbidity of NF is diabetes. Diabetes was reported in 60\% of patients diagnosed with $N F^{[11]}$. Risk factors for NF include immune deficiency, obesity, intravenous drug use, smoking, alcoholism, cancer, and chronic corticosteroid use $\mathrm{e}^{[12,13]}$.

The clinical signs of NF may not be distinguishable from cellulitis and erysipelas in the early stage. Findings supportive of NF are presence of pain extending beyond the affected areas, pain that is disproportionate to the lesions, and indistinct lesion borders. Bullae, vesicles, and necrosis also assist the diagnosis ${ }^{[14]}$. Early diagnosis is life-saving in NF patients.

The aim of our study was to determine areas of involvement, causative agents, risk factors, and mortality rates of $\mathrm{NF}_{\text {, which }}$ is rare but associated with high mortality and considered to be one of the infectious disease emergencies.

\section{Materials and Methods}

In this study, data collected from the medical records of patients treated and followed for NF in three clinics located in two universities (Ege University Orthopedics and Traumatology Clinic, Ege University Infectious Diseases and Clinical Microbiology Clinic, and Celal Bayar University Infectious Diseases and Clinical Microbiology Clinic) between November 2016 and December 2018 were analyzed retrospectively in terms of demographic characteristics, risk factors for infection, site of infection, clinical stage, 'Laboratory Risk Indicator for Necrotizing Fasciitis' (LRINEC) scores, surgical approaches used, departments involved in the operation, isolated microbial agents, laboratory parameters, empirical and agent-specific treatment regimens used and their durations, length of hospital stay, need for intensive care, and post-treatment 1-month survival. Six independent NF-associated biochemical parameters [blood C-reactive protein (CRP), leukocyte count, hemoglobin, sodium, creatinine, and glucose levels] were used for NF staging and probable NF risk was calculated using LRINEC scores. In this classification, a score $\geq 8$ was defined as high, 6-7 was defined as moderate, and $\leq 5$ was defined as low risk. NF is classified in three stages based on clinical findings. Stage 1 is limited to tenderness to palpation (extending beyond the lesion), erythema, swelling, calor (hot skin), while stage 2 is characterized by the formation of bullae (serous fluid) and skin fluctuation. Stage 3 is a more severe clinical presentation featuring crepitation, loss of sensation, darkening of the skin, and tissue necrosis progressing to gangrene ${ }^{[15,16]}$. Approval was obtained from the relevant departments to analyze the patients' files.

Diagnosis of NF diagnosis was based on the Centers for Disease Control and Prevention criteria ${ }^{[17]}$. NF was diagnosed clinically in patients with one or more of the following: pain, tenderness, erythema, ecchymosis, necrosis, hot skin, edema, and induration in the area of the lesion, bullae on an ecchymotic or erythematous base, subcutaneous crepitation, and fever. The diagnosis was supported by microbiological and laboratory findings and imaging methods. Of the routine laboratory parameters, leukocyte, hemoglobin, creatinine, sodium, and CRP levels 
before the antibiotic therapy and leukocyte and CRP levels at the end of treatment were evaluated. A reference range of 0-0.5 $\mathrm{mg} / \mathrm{dl}$ was used for CRP. Bacterial isolates were identified using VITEK ${ }^{\circ}$ MS (France) automated system. Antibiotic susceptibility of the isolates was assessed using European Committee on Antimicrobial Susceptibility Testing guidelines ${ }^{[18]}$. Patients diagnosed with NF were started on empirical broad-spectrum antibiotic therapy targeting Gram-negative, Gram-positive, and anaerobic pathogens/bacteria. Patients who were younger than 18 years of age and those who were followed up at another center were excluded.

\section{Statistical Analysis}

Statistical analyses were performed with SPSS 22.0 (IBM Inc., USA) statistical software and descriptive statistical methods were used. Mean initial and end-of-treatment leukocyte counts and CRP levels of the patients were compared using pairedsamples Student's t-test and the results were depicted as boxplot charts.

\section{Results}

A total of 18 patients [10 females, eight males; mean age 53.7 (19-86) years] diagnosed with NF were included in the study. History of trauma/surgery (8 cases-44.4\%), type 2 diabetes mellitus (5 cases-27.7\%), and decubitus wound (4 cases-22.2\%) were the most common predisposing factors.

Site of infection was lower extremity in ten cases (55.5\%), perianal-gluteal in five cases (27.7\%), and upper extremity in three cases (16.6\%). Based on whether the patients were clinically stable to receive anesthesia, 15 patients underwent debridement in the first 24 hours and the other three patients in the first 72 hours. The departments that performed debridement were orthopedics (39\%), plastic surgery (32\%), general surgery $(23 \%)$, obstetrics $(3 \%)$, and cardiovascular surgery $(3 \%)$, respectively. Debridement was performed once for 12 patients, twice for three patients, 3 times for one patient, 4 times for one patient, and 7 times for one patient. After debridement, ten patients required reconstruction, which was performed by plastic surgeons. All 18 patients were diagnosed as NF with X-ray. Furthermore, 10 (55.5\%) were examined by computed tomography (CT), $3(16.6 \%)$ by magnetic resonance imaging (MRI), and $1(5.55 \%)$ by ultrasonography (USG) and findings consistent with NF were detected in all cases.

Tissue samples of these 15 cases $(83.3 \%)$ were sent to the microbiology laboratory and causative agents were isolated in eight cases (53.3\%), five of which were polymicrobial. Clinical stages, LRINEC scores, empirical treatment approaches, isolated pathogens and their antibacterial resistance characteristics, total duration of treatment, and post-treatment 1-month survival of the patients are shown in Table 1.
The mean duration of antibiotic therapy was 35.5 (9-68) days. The mean length of hospital stay was 55 (11-186) days. Six patients (33.3\%) required intensive care during follow-up.

LRINEC scores were calculated and evaluated based on the patients' laboratory findings at time of admission. LRINEC scores were $\geq 8$ (high) in nine patients (50\%), 6-7 (moderate) in five patients $(27.7 \%)$, and $\leq 5$ (low) in four (22.2\%) of the 18 patients.

Fifteen patients were discharged with full recovery, while three patients died during follow-up. The mortality rate was $16.6 \%$. The 1-month survival rate after discharge was $100 \%$. In the 15 survivors, mean leukocyte counts were $19416.7 \pm 6136.6$ before treatment and $8583.3 \pm 2283.8$ after treatment and mean CRP levels were $24.1 \pm 13.0$ before treatment and $3.1 \pm 2.4$ after treatment (normal CRP $0.05 \mathrm{mg} / \mathrm{dl})(\mathrm{p}<0.001)$. These values are shown in Figure 1 .

\section{Discussion}

Although NF is considered to be a rare condition, its incidence is increasing as predisposing factors such as chronic diseases and diabetes become more common. Early diagnosis and treatment is a critical race against time for both clinicians and surgeons in order to prevent mortality and morbidity. A multidisciplinary approach increases the success of treatment in this patient group. Hence, specialists from infectious diseases and clinical microbiology, orthopedics and traumatology, plastic and reconstructive surgery, general surgery, obstetrics, and cardiovascular surgery were involved in the treatment of patients in our study.

Diagnosis may be one of the biggest challenges in the management of necrotizing soft tissue infections. In patients with soft tissue infection. Although the necrotic component is the distinguishing sign of $\mathrm{NF}_{\text {, the }}$ key point is clinical suspicion ${ }^{[6]}$. For a clinical condition as severe as $N F$, clinical staging as well as immediate recognition of at-risk patients and reaching a diagnosis are vital for successful treatment. In their retrospective observational study, Wong et al. ${ }^{[19]}$ stated that
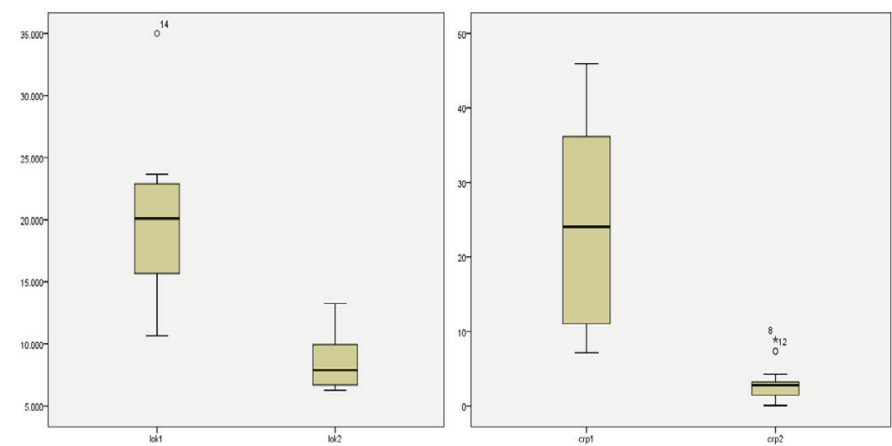

Figure 1. Change in leukocyte count and C-reactive protein value before and after treatment in patients who survived for one month after discharge 
determining LRINEC score and staging at-risk patients based on their biochemical parameters and estimating their probability of NF accordingly may provide guidance in diagnosis and treatment. In our study, $50 \%$ of the patients were identified as high-risk for NF (LRINEC score $\geq 8, \mathrm{n}=9$ patients) (Table 2,3 ).

The treatment of NF involves intravenous administration of empirical broad-spectrum antibiotics and emergency surgical debridement. Ischemia and hypoxia may make it difficult to achieve adequate antibiotic concentration at the site of infection. Therefore, neither a conservative approach with antibiotic alone nor surgical treatment alone is sufficient for treatment. The aim of surgical intervention is to eliminate all necrotic tissues, including muscle, fascia, and skin. Postoperative wound management and appropriate nutritional support are important for survival[ ${ }^{[4]}$. NF can be classified based on causative agents as polymicrobial (aerobic and anaerobic microorganisms) or monomicrobial (group A streptococci, community-acquired methicillin-resistant S. aureus). Etiology was polymicrobial in five of the eight patients in our study for whom an agent was isolated. For empirical antibiotic therapy, regimens such as glycopeptides or linezolid with broad-spectrum antibiotics such as carbapenems or piperacillin/tazobactam are recommended; clindamycin in combination with penicillin is recommended for monomicrobial NF caused by group A streptococci ${ }^{[20]}$. Antibiotic treatment must continue until the patient requires no further debridement and shows hemodynamic recovery, and this duration must be determined for each patient based on their individual circumstances ${ }^{[21]}$. Treatment durations varied among our patients, with antibiotherapy ranging from as short as nine days to as long as 68 days.

Table 1. The patients' clinical stages, LRINEC scores, empirical treatment approaches, isolated microorganisms and their resistance features, total treatment durations, and survival

\begin{tabular}{|c|c|c|c|c|c|c|c|}
\hline Patient & $\begin{array}{l}\text { Clinical } \\
\text { stage }\end{array}$ & $\begin{array}{l}\text { LRINEC } \\
\text { score }\end{array}$ & Empirical antibiotic & $\begin{array}{l}\text { Number of } \\
\text { debridements }\end{array}$ & $\begin{array}{l}\text { Sample type; isolated microorganism } \\
\text { (resistance traits) }\end{array}$ & $\begin{array}{l}\text { Total treatment } \\
\text { duration (days) }\end{array}$ & Survival \\
\hline 1 & 3 & 6 & Meropenem+tigecycline & 4 & Operative material; Negative culture & 45 & Yes \\
\hline 2 & 3 & 2 & Ertapenem & 1 & Operative material; Negative culture & 24 & Yes \\
\hline 3 & 3 & 12 & Colistin+tigecycline+linezolid & 1 & $\begin{array}{l}\text { Operative material; E. coli (ESBL+), P. } \\
\text { aeruginosa, P. mirabilis }\end{array}$ & 48 & No \\
\hline 4 & 3 & 6 & Tigecycline+amikacin & 1 & $\begin{array}{l}\text { Operative material; P. mirabilis } \\
\text { (carbapenem-resistant), K. pneumoniae } \\
\text { (carbapenem-resistant) }\end{array}$ & 23 & No \\
\hline 5 & 3 & 8 & Meropenem+daptomycin & 1 & Operative material; Negative culture & 9 & Yes \\
\hline 6 & 3 & 2 & Tigecycline & 1 & Operative material; Negative culture & 30 & Yes \\
\hline 7 & 3 & 6 & Ceftriaxone+metronidazole & 7 & Operative material; Negative culture & 27 & Yes \\
\hline 8 & 3 & 10 & Meropenem & 1 & & 10 & Yes \\
\hline 9 & 3 & 4 & Meropenem+linezolid & 1 & $\begin{array}{l}\text { Operative material; E. coli }(\mathrm{ESBL}+), E \text {. } \\
\text { gallinarum }\end{array}$ & 40 & Yes \\
\hline 10 & 3 & 10 & Ampicillin/sulbactam & 1 & & 17 & Yes \\
\hline 11 & 3 & 10 & Meropenem+linezolid & 1 & & 60 & Yes \\
\hline 12 & 3 & 5 & - & 2 & $\begin{array}{l}\text { Operative material; A. baumannii } \\
\text { (carbapenem-resistant), K. pneumoniae } \\
\text { (carbapenem-resistant) }\end{array}$ & 68 & Yes \\
\hline 13 & 3 & 7 & $\begin{array}{l}\text { Ampicillin/sulbactam+ } \\
\text { ciprofloxacin }\end{array}$ & 2 & Operative material; Negative culture & 35 & Yes \\
\hline 14 & 3 & 8 & $\begin{array}{l}\text { Meropenem+teicoplanin+ } \\
\text { clindamycin+ciprofloxacin }\end{array}$ & 3 & $\begin{array}{l}\text { Operative material; } A \text {. baumannii } \\
\text { (carbapenem-resistant) }\end{array}$ & 53 & Yes \\
\hline 15 & 3 & 8 & Meropenem+daptomycin & 1 & Operative material; Negative culture & 30 & Yes \\
\hline 16 & 3 & 10 & Piperacillin/tazobactam & 1 & $\begin{array}{l}\text { Operative material; S. haemolyticus } \\
\text { (methicillin-resistant) }\end{array}$ & 25 & Yes \\
\hline 17 & 3 & 10 & $\begin{array}{l}\text { Colistin+meropenem+ } \\
\text { daptomycin }\end{array}$ & 1 & Operative material; E. coli (ESBL-) & 32 & Yes \\
\hline 18 & 3 & 6 & Tigecycline & 2 & $\begin{array}{l}\text { Operative material; } P \text {. aeruginosa, } A \text {. } \\
\text { baumannii (carbapenem-resistant), } C \text {. } \\
\text { striatum, K. pneumoniae (ESBL-), E. coli } \\
(\mathrm{ESBL+)}\end{array}$ & 63 & No \\
\hline
\end{tabular}


In a retrospective, single-center study, 35\% of patients who presented with pain, tenderness, and hot skin were diagnosed with cellulitis, superficial erysipelas, or abscess instead of NF. Initiation of antibiotherapy for a misdiagnosis masks the clinical signs and delays appropriate treatment for $\mathrm{NF}$, thus increasing the rate of complications ${ }^{[22]}$. The effective use of LRINEC score in our study resulted in proper management of our patients. However, the mortality of two patients with scores of six in our study raises suspicion regarding the reliability of LRINEC score. In a retrospective study Neeki et al. ${ }^{[23]}$ investigated the ability of LRINEC score to discriminate NF in 948 patients treated for cellulitis in the emergency department over a 10year period. Thirty (63.8\%) of 47 patients diagnosed with NF had LRINEC scores $<5$ and were at low risk and the authors stated that LRINEC score may not always be the right tool for differentiating cellulitis from NF in patients presenting to the emergency department.

There is no consensus on whether to perform surgical debridement by removing all necrotic tissue at once or through repeated

Table 2. Laboratory risk markers for necrotizing fasciitis ${ }^{[17]}$

\begin{tabular}{l|l}
\hline Value & LRINEC score \\
\hline C-reactive protein $(\mathrm{mg} / \mathrm{dl})$ & \\
\hline$<15$ & 0 \\
\hline$>15$ & 4 \\
\hline Leukocyte count $\left(10^{3} / \mu \mathrm{l}\right)$ & \\
\hline$<15$ & 0 \\
\hline $15-25$ & 1 \\
\hline$>25$ & 2 \\
\hline Hemoglobin level $(\mathrm{g} / \mathrm{dl})$ & \\
\hline$>13.5$ & 0 \\
\hline $11-13.5$ & 1 \\
\hline$<11$ & 2 \\
\hline Sodium $(\mathrm{mmol} / \mathrm{l})$ & \\
\hline$\geq 135$ & 0 \\
\hline$<135$ & 2 \\
\hline Creatinine $(\mathrm{mg} / \mathrm{dl})$ & \\
\hline$\geq 1.6$ & 0 \\
\hline$>1.6$ & 2 \\
\hline Blood glucose $(\mathrm{mg} / \mathrm{dl})$ & \\
\hline$\leq 180$ & 0 \\
\hline$>180$ & 1
\end{tabular}

Table 3. Necrotizing fasciitis staging according to LRINEC score $^{[17]}$

\begin{tabular}{l|l|l}
\hline Stage & Score & Probability of necrotizing fasciitis (\%) \\
\hline Low & $\leq 5$ & 50 \\
\hline Moderate & $6-7$ & $50-75$ \\
\hline High & $\geq 8$ & $>75$
\end{tabular}

debridements in NF. The amount of "aggressive debridement" is not defined in the literature. The approach is generally left to the surgeon's discretion ${ }^{[24]}$. Nevertheless, numerous studies have recommended that the first debridement should be performed within the first 24 hours, and the wound must be re-evaluated 24-48 hours after the first debridement in terms of progression and need for further debridement. The average number of debridements reported in the literature is $3^{[25,26]}$. In our study, the first debridement was performed within the first 24 hours in 15 patients, and the number of debridements was 1 for 12 patients, 2 for three patients, 3 for one patient, 4 for one patient, and 7 for one patient.

In the literature, the rate of mortality due to NF is $11-36 \%\left[{ }^{[5]}\right.$. In our study, this rate was $16.6 \%$. We attribute our relatively low mortality rate to early NF diagnosis, urgent debridement, and the administration of appropriate and effective antibiotherapy.

Radiological imaging may be used as a supportive method in the diagnosis of NF. Fascial thickening and gas in the subcutaneous tissue can be visualized using $\mathrm{CT}$, MRI, or USG. Magnetic resonance imaging is more sensitive and demonstrates liquefactive necrosis of the adipose tissue $\mathrm{e}^{[27,28]}$. Direct radiography is the gold standard for patients whose condition is too poor to be referred for radiological tests (CT, MRI) for diagnosis of NF. The appearance of gas in the soft tissue on X-ray is a diagnostic indicator. Loss of fascial contrast enhancement in contrast CT and abnormal signal changes in the deep tissues which do not show contrast enhancement on T2weighted images in MRI facilitate diagnosis. Magnetic resonance imaging is a more sensitive diagnostic tool but can lead to loss of time. Ultrasonography is another auxiliary test that can be performed quickly in emergency conditions. Although it is especially sensitive in visualizing soft tissue abscesses, it has low sensitivity ${ }^{[29]}$. In our study, after all patients were diagnosed with X-ray, additional imaging was performed in some cases to confirm the diagnosis and determine the extent of NF. Findings consistent with NF were detected concurrently with MRI in ten patients $(55.5 \%)$, with CT in three patients $(16.6 \%)$, and with USG in one patient (5.5\%).

Numerous studies in the literature have cited open fractures, chronic skin ulcers, abscesses, and injection as causes of $\mathrm{NF}^{[25,29,30]}$. Advanced age, chronic disease, diabetes, or immunosuppressive therapies were identified as risk factors for the development of $N \mathrm{~F}^{[28,29]}$. Consistent with the literature, the most common predisposing factors in our study were history of trauma/surgery in eight cases (44.4\%), type 2 DM in five cases (27.7\%), and decubitus wound in four cases (22.2\%). Necrotizing fasciitis developed as a result of open fracture in four patients and decubitus wound in four patients. 
The importance of early diagnosis and aggressive treatment has been discussed in the literature ${ }^{[31]}$. However, there is no information concerning the multidisciplinary approach to surgery. We believe that the disease was controlled earlier in our patients since the necessary initial debridement for NF spread was performed appropriately by the orthopedics and traumatology department in conjunction with the departments of cardiovascular surgery, general surgery, and obstetrics. Therefore, presence of relevant specialists in the operating room and their involvement in surgery are important for the success of surgical treatment in NF cases with extremity involvement. The main limitations of our study are the small sample size, not being a randomized, controlled study, inability to obtain complete patient data due to the retrospective design, and that standard radiological tests could not be performed on the patients. However, since all patients underwent debridement and multidisciplinary treatment, we believe that our study is valuable in terms of evaluating the effects of these interventions on mortality and morbidity.

\section{Conclusion}

NF is a rare and complicated soft tissue infection with high mortality rates and is considered one of the infectious disease emergencies. The most important factor in diagnosis is clinical suspicion. The previously described LRINEC scoring based on laboratory values may facilitate the diagnosis. For patients with suspected NF, surgical debridement, a multidisciplinary approach, and infection control with appropriate antibiotherapy reduces mortality rates.

\section{Ethics}

Ethics Committee Approval: Since this was a retrospective study institutional review board approval was not received.

Informed Consent: Since this was a retrospective study informed consent was not received.

Peer-review: Externally and internally peer-reviewed.

\section{Authorship Contributions}

Surgical and Medical Practices: A.M.Ö., N.Ö., O.S., M.I.T., D.A., Concept: M.I.T., A.M.Ö., N.Ö., Design: M.I.T., A.M.Ö., Ş.Ş.A., Data Collection or Processing: M.I.T., A.M.Ö., N.Ö., S..S..A., I.Y.Ş., Analysis or Interpretation: M.I.T., A.M.Ö., H.A.E., S.S.A.A., Literature Search: H.A.E., O.S., A.M.Ö., D.A., Writing: O.S., D.A., H.A.E., A.M.Ö., Ş.S..A.

Conflict of Interest: No conflict of interest was declared by the authors.

Financial Disclosure: The authors declared that this study received no financial support.

\section{References}

1. Liu YM, Chi CY, Ho MW, Chen CM, Liao WC, Ho CM, Lin PC, Wang JH. Microbiology and factors affecting mortality in necrotizing fasciitis. J Microbiol Immunol Infect. 2005;38:430-5.

2. Swartz MN, Pasternack MS. Cellulitis, necrotizing fasciitis, and subcutaneous tissue infections. In: Mandell GL, Bennett JE, Dolin R (eds). Principles and Practice of Infectious Diseases. $7^{\text {th }}$ ed. New York: Churchill Livingstone, 2010:1289-312.

3. Ozgenel GY, Akin S, Kahveci R, Ozbek S, Ozcan M. Clinical evaluation and treatment results of 30 patients with necrotizing fasciitis. Ulus Travma Acil Cerrahi Derg. 2004;10:110-4.

4. Misiakos EP, Bagias G, Patapis P, Sotiropoulos D, Kanavidis P, Machairas A. Current concepts in the management of necrotizing fasciitis. Front Surg. 2014;1:36.

5. Jabbour G, El-Menyar A, Peralta R, Shaikh N, Abdelrahman H, Mudali IN, Ellabib $\mathrm{M}, \mathrm{Al}$-Thani $\mathrm{H}$. Pattern and predictors of mortality in necrotizing fasciitis patients in a single tertiary hospital. World J Emerg Surg. 2016;11:40.

6. Anaya DA, Dellinger EP. Necrotizing soft-tissue infection: Diagnosis and management. Clin Infect Dis. 2007;44:705-10.

7. Wilson B. Necrotizing fasciitis. Am Surg. 1952;18:416-31.

8. Carter PS, Banwell PE. Necrotising fasciitis: A new management algorithm based on clinical classification. Int Wound J 2004;1:189-98.

9. Bisno AL, Stevens DL. Streptococcal infections of skin and soft tissues. N Engl J Med. 1996;334:240-5.

10. Levine EG, Manders SM. Life-threatening necrotizing fasciitis. Clin Dermatol. 2005;23:144-7.

11. Dufel $\mathrm{S}$, Martino M. Simple cellulitis or a more serious infection. J Fam Pract. 2006;55:396-400.

12. Childers BJ, Potyondy LD, Nachreiner R, Rogers FR, Childers ER, Oberg KC, Hendricks DL, Hardesty RA. Necrotizing fasciitis: a fourteen-year retrospective study of 163 consecutive patients. Am Surg. 2002;68:109-16.

13. Geusens E, Pans $S$, Van Breuseghem I, Knockaert D. Necrotizing fasciitis of the leg presenting with chest wall emphysema. Eur J Emerg Med. 2004;11:49-51.

14. Young MH, Aronoff DM, Engleberg NC. Necrotizing fasciitis: pathogenesis and treatment. Expert Rev Anti Infect Ther. 2005;3:279-94.

15. Wong $\mathrm{CH}$, Wang YS. The diagnosis of necrotizing fasciitis. Curr Opin Infect Dis. 2005;18:101-6.

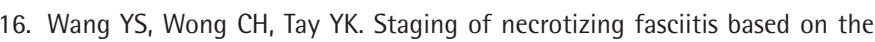
evolving cutaneous features. Int J Dermatol 2007;46:1036-41.

17. Centers for Disease Control and Prevention (CDC). Last accessed date: 22 January 2019. Available from: https://www.cdc.gov/groupastrep/diseaseshcp/necrotizing-fasciitis.html

18. European Committee on Antimicrobial Susceptibility Testing (EUCAST) Clinical Breakpoints for Bacteria. Last accessed date: 14 March 2019. Available from: http://www.eucast.org/clinical_breakpoints/

19. Wong $\mathrm{CH}$, Khin LW, Heng KS, Tan KC, Low CO. The LRINEC (Laboratory Risk Indicator for Necrotizing Fasciitis) score: a tool for distinguishing necrotizing fasciitis from other soft tissue infections. Crit Care Med. 2004;32:1535-41.

20. Stevens DL, Bisno AL, Chambers HF, Dellinger EP, Goldstein EJ, Gorbach SL, Hirschmann JV, Kaplan SL, Montoya JG, Wade JC; Infectious Diseases Society of America. Practice guidelines for the diagnosis and management of skin and soft tissue infections: 2014 update by the Infectious Diseases Society of America. Clin Infect Dis. 2014;59:10-52. 
21. Lauerman MH, Kolesnik O, Sethuraman K, Rabinowitz R, Joshi M, Clark E, Stein D, Scalea T, Henry S. Less is more? Antibiotic duration and outcomes in Fournier's gangrene. J Trauma Acute Care Surg. 2017;83:443-8.

22. Angoules AG, Kontakis G, Drakoulakis E, Vrentzos G, Granick MS, Giannoudis PV. Necrotising fasciitis of upper and lower limb: a systematic review. Injury. 2007;38(Suppl 5):19-26.

23. Neeki MM, Dong F, Au C, Toy J, Khoshab N, Lee C, Kwong E, Yuen HW, Lee J, Ayvazian A, Lux P, Borger R. Evaluating the Laboratory Risk Indicator to Differentiate Cellulitis from Necrotizing Fasciitis in the Emergency Department. West J Emerg Med. 2017;18:684-9.

24. Sudarsky LA, Laschinger JC, Coppa GF, Spencer FC. Improved results from a standardized approach in treating patients with necrotizing fasciitis. Ann Surg. 1987;206:661-5.

25. Elliott DC, Kufera JA, Myers RA. Necrotizing soft tissue infections. Risk factors for mortality and strategies for management. Ann Surg. 1996;224:672-83.

26. Kobayashi L, Konstantinidis A, Shackelford S, Chan LS, Talving $P$, Inaba $K$, Demetriades D. Necrotizing soft tissue infections: delayed surgical treatment is associated with increased number of surgical debridements and morbidity. J Trauma. 2011;71:1400-5.

27. Wysoki MG, Santora TA, Shah RM, Friedman AC. Necrotizing fasciitis: CT characteristics. Radiology. 1997;203:859-63.

28. Arslan A, Pierre-Jerome C, Borthne A. Necrotizing fasciitis: Unreliable MRI findings in the preoperative diagnosis. Eur J Radiol. 2000;36:139-43.
29. Bonne SL, Kadri SS. Evaluation and management of necrotizing soft tissue infections. Infect Dis Clin North Am. 2017;31:497-511.

30. Bellapianta JM, Ljungquist $K$, Tobin E, UhI R. Necrotizing fasciitis. J Am Acad Orthop Surg. 2009;17:174-82.

31. Sartell M, Malangoni MA, Abu-Zidan FM, Griffiths EA, Di Bella S, McFarland LV, Eltringham I, Shelat VG, Velmahos GC, Kelly CP, Khanna S, Abdelsattar ZM, Alrahmani L, Ansaloni L, Augustin G, Bala M, Barbut F, Ben-Ishay O, Bhangu A, BiffI WL, Brecher SM, Camacho-Ortiz A, Cainzos MA, Canterbury LA, Catena F, Chan S, Cherry-Bukowiec JR, Clanton J, Coccolini F, Cocuz ME, Coimbra R, Cook CH, Cui Y, Czepiel J, Das K, Demetrashvili Z, Di Carlo I, Di Saverio S, Dumitru IM, Eckert C, Eckmann C, Eiland EH, Enani MA, Faro $M$, Ferrada $P$, Forrester JD, Fraga GP, Frossard JL, Galeiras R, Ghnnam W, Gomes CA, Gorrepati V, Ahmed MH, Herzog T, Humphrey F, Kim JI, Isik $A$, Ivatury $R$, Lee $Y Y$, Juang $P$, Furuya-Kanamori L, Karamarkovic A, Kim PK, Kluger Y, Ko WC, LaBarbera FD, Lee JG, Leppaniemi A, Lohsiriwat $V$, Marwah S, Mazuski JE, Metan G, Moore EE, Moore FA, Nord CE, Ordoñez CA, Júnior GA, Petrosillo N, Portela F, Puri BK, Ray A, Raza M, Rems M, Sakakushev BE, Sganga G, Spigaglia $P$, Stewart DB, Tattevin $P$, Timsit JF, To KB, Tranà C, Uhl W, Urbánek L, van Goor H, Vassallo A, Zahar JR, Caproli E, Viale P. WSES guidelines for management of Clostridium difficile infection in surgical patients. World J Emerg Surg. 2015;10:38. 